Volume: 14 Issue: 1 Year: 2017

\title{
'The analyzing of elementary school students' social skills and their social emotional learning levels according to some variables ${ }^{1}$
}

\author{
Hadiye Küçükkaragöz ${ }^{2}$ \\ Fatma Erdoğan ${ }^{3}$
}

\begin{abstract}
Social skills and emotional intelligence are terms which are related closely with each other and determine on human behaviors, which arranger people's relations with each other. As using this important relation as a base, this research has been made to analyze whether elementary school students' social skills and social emotional learning levels reflect a significant difference by variables such as gender, age, number of siblings, which the person is in order of siblings, educational case and professions of mother - father, whether there is migration in family or not. This research, is a descriptive study. A sampling group which is the most accessible and which will provide maximum saving, and the proper sampling method which provides an opportunity to work have been used. Based on this purpose $1364^{\text {th }}$ grade elementary school students have participated in the research. On the study, social skill scale and social emotional learning scale have been used in terms of determining on elementary school's forth grade students' social skills level and social emotional learning level. Data has been analyzed, using statistic analyses (Mann-Whitney Test, KruskalWallis Test) which are not parametric from SPSS 23 program. As a result of the research, it has been determined that students' social skills' level changes in significant level by variables of age, the situation on whether there is a migration in family or not and number of sibling. On the other hand, when results of the study are examined on the base of social emotional learning, students who have gone on the same class education and who are ten years old have got higher social emotional learning points than those who are nine years old; students who have lived in Izmir for ten years or more than ten years have got higher social emotional learning points at significant rate than those who have lived in Izmir for nine years or shorter. It has been determined that there is a positive and significant relation at high rate between students' social skills' points and their social emotional learning level.
\end{abstract}

Keywords: Social skill; social emotional learning; elementary school.

\section{Introduction}

Today, the ways to reach information have been some easier in every passing day. Moreover, educational materials have risen and varied with the developing technologies. On the other hand, information which is easily reached and materials which increase support academic success of students, it becomes complex to obtain information and what is more important to the point of information configuration. In this environment which becomes complex as it rises, another point which contributes to students' academic successes is; social emotional learning which would

\footnotetext{
1 This research was presented at $15^{\text {th }}$ International Primary Teacher Education Symposium as oral presentation.

${ }^{2}$ Assist. Prof. Dr., Dokuz Eylül University, Faculty of Education, hadiye.kkaragoz@,deu.edu.tr

${ }^{3}$ Res. Assist., Dokuz Eylül University, Faculty of Education, fatma.erdogan@,deu.edu.tr
} 
Küçükkaragöz, H., \& Erdoğan, F. (2017). The analyzing of elementary school students' social skills and their social emotional learning levels according to some variables. Journal of Human Sciences, 14(1), 39-48. doi:10.14687/ihs.v14i1.4211

be defined as a multiple skill (Goleman, 1995). When it is considered that we live in a social world, besides academic success; social emotional learning 's importance has increased on that individuals understand their own feelings and others' feelings, on respecting differences, on listening correctly, on effective communication and on taking decision as thinking (Elias, 1999).

Schools working for developing academic achievements of students and their social-emotional learning as a whole will be more successful. On the other hand, social and emotional competence is the ability of the individual to understand, manage and express social and emotional aspects of their life, which ensures that life tasks such as learning, building up relationships, solving problems of daily life are managed successfully (Elias et al. 1997). Goleman (1995) pinpoints that social and emotional intelligence is a complex and multifaceted ability that is effective on all crucial fields of life, including school. Elias et al. (1997) emphasize that there will be no success without social emotional skills, and states that the common denominator of various successful schools is having a system improving social emotional learning of students. Accordingly, social emotional learning component is what distinguishes effective schools. In other words, social emotional learning encourages academic learning (Zins, 2004).

It has been known that the learned skills (social skills) which belong to individuals who have powerful emotional intelligence which would be defined as correct and effective emotional information processing capacity (Mayer and Salovey, 1995), and which are used in reaching a goal and getting support from other individuals (Kelly, 1982; quoted from: Dicle, 2006). Furthermore, social skills on social emotional learning can affect on individuals' school success, social relations and adaptation power (Şahin, 2001). Social skills which start in childhood period are beneficial in the event that individual would go on healthy and agreeable relations. Moreover, social skills increase persons' life quality, aid that persons get their targets. On the other hand, it is known that feelings have got important role in that the development and behaviour occur (Özabac1, 2004). Students acquire social skills at school, which is a social environment and where foundations of socialization are laid (Özsar1, 2015). Gaining and developing social skills are important in elementary school years that the base of education life is created.

In a study conducted with secondary school students, Kabakç1 (2006) inquired into social emotional learning skills of students. For this purpose, it was determined whether class level and socioeconomical level affect social emotional learning significantly. In the study in which 431 students in total from $6^{\text {th }}, 7^{\text {th }}$ and $8^{\text {th }}$ grades participated, it was found out that the level of social emotional learning skills of female students is higher than that of male students and that the level of social emotional learning skills of students at $6^{\text {th }}$ grade are better than those of students at $8^{\text {th }}$ grade.

In the study within the scope of which the relationship between social skill levels and emotional intelligence levels of university students, Dicle (2006) determined that there exists a high-level, positive and meaningful relationship between levels of total social skill and emotional intelligence of students.

In another study conducted with the participation of 307 secondary school students, the relationship between social emotional learning abilities of students and their attitudes towards the school were examined. Despite differences in some subscales, it was found, looking at the total score from the scale, that gender, class level, age, education level of parents and income level variables of the students did not affect the social emotional learning ability of the students at a significant level (Kutluay Çelik, 2014). 
Küçükkaragöz, H., \& Erdoğan, F. (2017). The analyzing of elementary school students' social skills and their social emotional learning levels according to some variables. Journal of Human Sciences, 14(1), 39-48. doi:10.14687/ihs.v14i1.4211

In the study in which alienation of students, who are studying at $4^{\text {th }}$ and $5^{\text {th }}$ grades at elementary level, towards school and their social abilities are investigated according to gender, socioeconomical status, education level of parents, number of students at the class they are studying, a significant difference between social skill points of students and education levels of their mothers has been identified. According to this, female students, in respect of gender variable, exhibit social ability behaviours at a higher level compared to male students. In addition, social ability levels of students whose mothers are university graduates are higher than those, whose mothers are illiterate (Özsar1, 2015).

Taking into account that people live within a social environment and that they are obliged to adopt the environment they are living in so as to accomplish their life tasks, the necessity of improving both social abilities and social emotional learning of individuals is understood. Because social skills and social emotional learning are important concepts that affect the behavior of people and the relationships between people. However, academic achievements of students are also related to social skill and social emotional learning concepts. At the same time, both concepts are closely related (Özabac1, 2004). Levels of social skills and social emotional learning of individuals may differ based on various variables (Uz Baş, 2003; Dicle, 2006; Kabakçı and Korkut, 2008; Payton et al. 2008; Durualp, 2014). Given that primary school education constitutes a basis for further education phases, social skill and social emotional learning levels that primary school students have, become important. In this context, examination of social skills and social emotional learning levels of $4^{\text {th }}$ grade primary school students, who will begin attending the secondary school a year later, according to certain variables and evaluation of the relationship between these two variables constitute the purpose of this study. For this purpose, it was examined whether social skills and social emotional learning levels of $4^{\text {th }}$ grade students in primary schools exhibit significant differences in respect of variables of gender, age, number of siblings, the birth order of the individual among siblings, education levels/occupations of parents, how many years they are living in Izmir for, if there is migration within the family, with whom the student lives together. When the literature was examined, it was determined that there were not many studies investigating social skills and social emotional learning levels of the students at the primary school level, and that the studies conducted generally examined only the social skills or only the social emotional learning levels with students at higher levels. It is aimed to contribute to the field in this respect with this study, which is conducted by considering the importance of these two variable and the close relation between them.

\section{Research Methodology}

This research is a descriptive research and it has been made in terms of analyzing whether elementary school students' social emotional learning skills differ in significant level (p.05) by some variables.

A sampling group which is the most accessible and which will provide maximum saving, and the proper sampling method which provides an opportunity to work have been used (Büyüköztürk et al. 2014). The study's sampling consists of total 136 elementary school students who go on forth grade at two different elementary schools in Buca, İzmir which is accessed by the proper sampling method.

\subsection{Data Collection Tools}

On the study, social skill scale and social emotional learning scale have been used in terms of determining on elementary school's forth grade students' social skills level and social emotional learning level. 
Küçükkaragöz, H., \& Erdoğan, F. (2017). The analyzing of elementary school students' social skills and their social emotional learning levels according to some variables. Journal of Human Sciences, 14(1), 39-48. doi:10.14687/ihs.v14i1.4211

\section{- Social Skill Scale}

The scale which was developed by Yurdakavuştu and Küçükkaragöz (2011) consists of 19 items. The scale's internal consistency reliability coefficient has been calculated as 0.87 . Within the concept of this research, the scale' $s$ internal consistency reliability coefficient has been determined as 0.87 . The scale which is developed to determine on elementary school students' social skills level is a scale in type of likert with 4 degrees. High point which is taken from the scale shows that social skill level is high.

\section{- Social Emotional Learning Scale}

Validity and reliability of Turkish form for the scale which was developed by Corn, Spybrook, Evergreen and Blinkiewicz (2009) have been analyzed by Arslan and Akin (2013). On the analyze, the scale's internal consistency reliability coefficient has been calculated as 0.90 and its test-retest reliability coefficient has been calculated as 0.71 . Within the concept of research, the scale's internal consistency reliability coefficient has been calculated again and it has been determined as 0.91 . The scale which is used to analyze elementary school students' social emotional learning level is a scale as type of likert with 5 degrees which consists of 20 items. The scale consists of three dimensions: first six items are about to describe duty, seven-thirteenth articles are about peer relations and the last seven articles are about to self-regulation dimension. Points which are gotten from the total of scale show individual's social emotional learning level. High points which are gotten from the scale indicate that social emotional learning level is high. Within the concept of this study which is made, analyses have been made through total points which are gotten from the scale.

\subsection{Data Analysis}

Before data analysis is started, it has been controlled whether data indicates normal distribution or not. Mode, median, mean values, coefficients of skewness and kurtosis have been calculated for two scales. Moreover, Kolmogorov-Smirnow values have been considered and it has been determined on whether data indicates normal distribution or not. Thus, data has been analyzed, using statistic analyses (Mann-Whitney Test, Kruskal-Wallis Test) which are not parametric from SPSS 23 program. Moreover, spearman's rank correlation coefficient technique has been used to analyze the relation between students' social skills and social emotional learning level.

\section{Results}

This research has been made to analyze whether elementary school students' social skills and social emotional learning levels reflect a significant difference by variables such as gender, age, number of siblings, which the person is in order of siblings, educational case and professions of mother-father, whether there is migration in family or not. The research findings related to students' psycho-social features and their social skill points are given in table 1.

Table 1: Results of Mann Whitney U-Test Related to Students' Psycho-Social Features and Their Social Skill Points

\begin{tabular}{llllllc}
\hline Variables & & $\mathrm{N}$ & $\begin{array}{l}\text { Mean of } \\
\text { rank }\end{array}$ & $\begin{array}{l}\text { Total of } \\
\text { rank }\end{array}$ & $\mathrm{U}$ & $\mathrm{p}$ \\
\hline Gender & Girl & 65 & 71.65 & 4657.5 & 2102.5 & 0.37 \\
& Boy & 71 & 65.61 & 4658.5 & & \\
\hline Age & 9 years old & 70 & 60.41 & 4228.5 & 1743.5 & $0.01^{*}$ \\
& 10 years old & 66 & 77.08 & 5087.5 & & \\
\hline $\begin{array}{l}\text { Mother's } \\
\text { working } \\
\text { situation }\end{array}$ & Working & 35 & 77.10 & 2698.5 & \multirow{2}{*}{1466.5} & 0.13 \\
\hline
\end{tabular}


Küçükkaragöz, H., \& Erdoğan, F. (2017). The analyzing of elementary school students' social skills and their social emotional learning levels according to some variables. Journal of Human Sciences, 14(1), 39-48. doi:10.14687/ihs.v14i1.4211

\begin{tabular}{|c|c|c|c|c|c|c|}
\hline $\begin{array}{l}\text { How many } \\
\text { years she/he } \\
\text { has lived in } \\
\text { Izmir }\end{array}$ & 10 year and over & 69 & 69.30 & 4158.0 & 1812.0 & 0.22 \\
\hline $\begin{array}{l}\text { As to whether } \\
\text { there is } \\
\text { migration in } \\
\text { family }\end{array}$ & Non-available & 61 & $\begin{array}{l}70.75 \\
65.69\end{array}$ & $\begin{array}{l}4316.0 \\
3685.0\end{array}$ & 1540.0 & $0.03 *$ \\
\hline $\begin{array}{l}\text { Whom he/she } \\
\text { lives with }\end{array}$ & $\begin{array}{l}\text { Nuclear family } \\
\text { Extended family }\end{array}$ & $\begin{array}{l}116 \\
20 \\
\end{array}$ & $\begin{array}{l}69.17 \\
64.60 \\
\end{array}$ & $\begin{array}{l}8024.0 \\
1292.0 \\
\end{array}$ & 1082.0 & 0.63 \\
\hline
\end{tabular}

According to table 1 there is significant difference between the variables of age and social skill points $(\mathrm{p}<0.05)$. Accordingly, social skill points of students that they are ten years old are higher than students who are nine years old. On this research, it has been determined that social skill level of those who go on the same class training and are older ones are higher than those who are at smaller age.

Moreover, it is seen that there is a significant difference between social skill level and the situation on whether they have migrated or not. According to results, it can be said that students whose family have migrated from a place to another have got higher social skill level $(p<0.05)$. It is thought that the effort which individual has got to adapt in new environment where is migrated would cause this situation.

On the other hand, it is seen that there is not significant difference between social skill points and students' gender, the situation on whether mother works or not, on how many years she/he has lived in Izmir and on whom she / he lives with in family ( $\mathrm{p}>0.05)$. Table 2 shows the results of kruskal-wallis test related to students' psycho-social features and their social skill points.

Table 2: Results of Kruskal-Wallis Test Related to Students' Psycho-Social Features and Their Social Skill Points

\begin{tabular}{llllllll}
\hline Variables & & $\mathrm{N}$ & $\begin{array}{l}\text { Mean of } \\
\text { rank }\end{array}$ & sd & $\mathrm{X}^{2}$ & $\mathrm{p}$ & $\begin{array}{l}\text { Significant } \\
\text { difference }\end{array}$ \\
\hline $\begin{array}{l}\text { Number of } \\
\text { siblings }\end{array}$ & Singleton & 18 & 52.11 & 3 & 11.18 & $0.011^{*} \begin{array}{l}\text { two } \\
\text { siblings- } \\
\text { singleton }\end{array}$ \\
& $\begin{array}{l}\text { One } \\
\text { sibling } \\
\text { Two } \\
\text { siblings }\end{array}$ & 50 & 59.94 & & & & \\
& $\begin{array}{l}\text { Three and } \\
\text { over }\end{array}$ & 30 & 74.63 & & & two siblings \\
- one sibling
\end{tabular}


Küçükkaragöz, H., \& Erdoğan, F. (2017). The analyzing of elementary school students' social skills and their social emotional learning levels according to some variables. Journal of Human Sciences, 14(1), 39-48. doi:10.14687/jhs.v14i1.4211

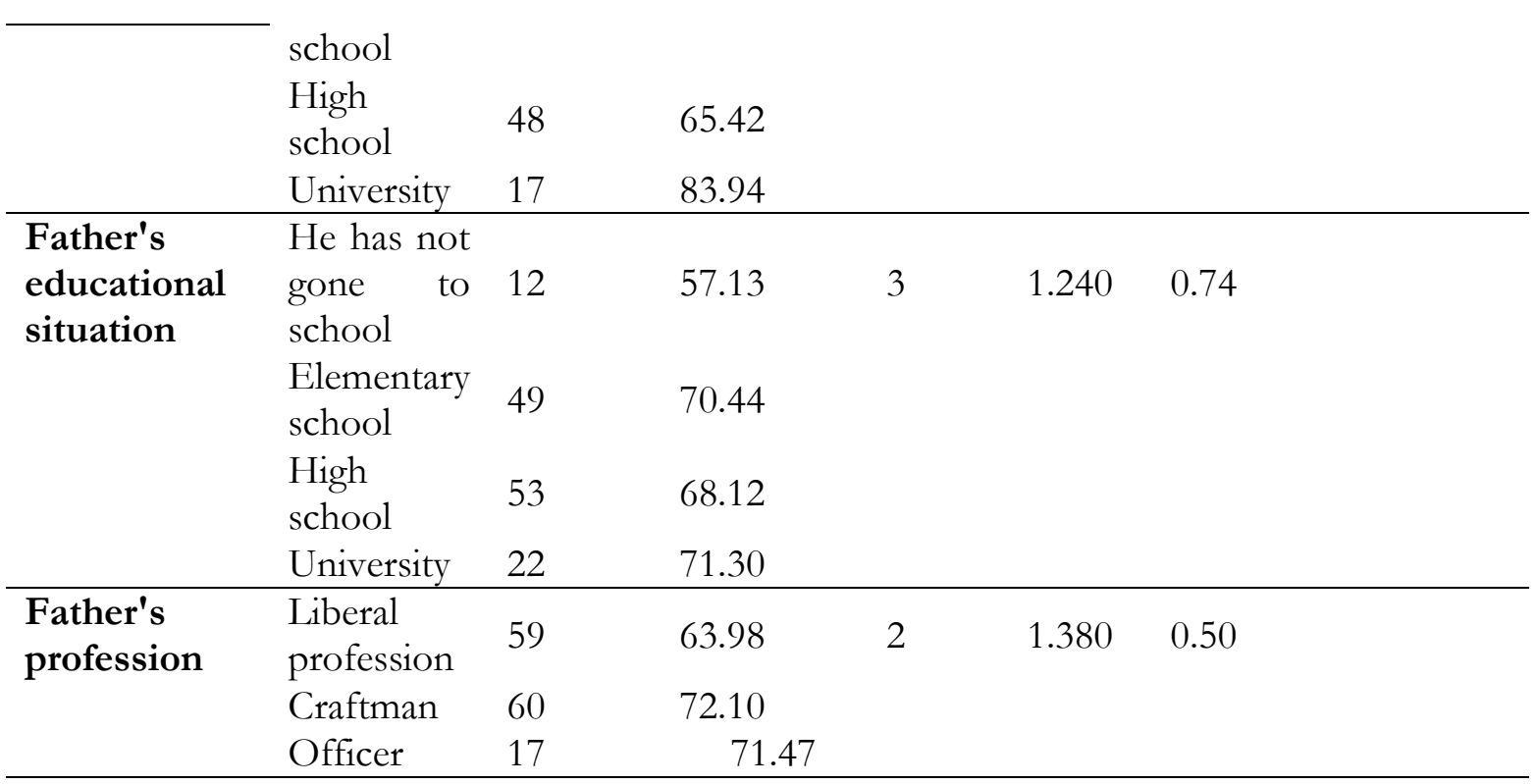

As seen in table 2, when Kruskal-Wallis Test's results has been analyzed about students' psychosocial features and their social skills' points, it is seen that there is significant difference between number of siblings and social skill points $(\mathrm{p}<0.05)$. The source of difference can be determined on multiple comparison tests which are not parametric in order to determine on which groups have got significant difference, as Mann Whitney U-Test is applied (Büyüköztürk, 2013; Can,2014).

As depending on analyses which a have been made on significancy of difference which occurs in social skills; it can be said that students who have got two siblings have got better level on social skills than students who are singleton, namely, who have not got sibling. Similarly, it can be said that students who have got two siblings have higher social skill level than those who have got one sibling. On the other hand, it has been determined that there is not a relation at significant level between variables on which child she /he is, mother's educational situation, father's educational situation and father's profession and social skill points $(\mathrm{p}>0.05)$. The research findings related to students' psycho-social features and their social emotional learning points are given in table 3.

Table 3: Results of Mann Whitney U-Test Related to Students' Psycho-Social Features and Their Social Emotional Learning Points

\begin{tabular}{|c|c|c|c|c|c|c|}
\hline Variables & & $\mathrm{N}$ & $\begin{array}{c}\text { Mean of } \\
\text { rank }\end{array}$ & $\begin{array}{c}\text { Total of } \\
\text { rank }\end{array}$ & $\mathrm{U}$ & $\mathrm{p}$ \\
\hline \multirow[t]{2}{*}{ Gender } & Girl & 65 & 70.19 & 4562.5 & \multirow[t]{2}{*}{2197.5} & \multirow[t]{2}{*}{0.63} \\
\hline & Boy & 71 & 66.95 & 4753.5 & & \\
\hline \multirow[t]{2}{*}{ Age } & 9 years old & 70 & 60.21 & 4215.0 & \multirow[t]{2}{*}{1730.0} & \multirow[t]{2}{*}{$0.01 *$} \\
\hline & 10 years old & 66 & 77.29 & 5101.0 & & \\
\hline \multirow{2}{*}{$\begin{array}{l}\text { Mother's } \\
\text { working } \\
\text { situation }\end{array}$} & Working & 35 & 71.74 & 2511.0 & \multirow{2}{*}{1654.0} & \multirow{2}{*}{0.57} \\
\hline & Not working & 101 & 67.38 & 6805.0 & & \\
\hline \multirow{2}{*}{$\begin{array}{l}\text { How many } \\
\text { years she/he } \\
\text { has lived in } \\
\text { Izmir }\end{array}$} & \multirow{2}{*}{$\begin{array}{l}1-9 \text { year } \\
10 \text { year and } \\
\text { over }\end{array}$} & 69 & 56.66 & 3909.5 & \multirow[t]{2}{*}{1494.5} & \multirow[t]{2}{*}{$0.006^{*}$} \\
\hline & & 60 & 74.59 & 4475.5 & & \\
\hline
\end{tabular}


Küçükkaragöz, H., \& Erdoğan, F. (2017). The analyzing of elementary school students' social skills and their social emotional learning levels according to some variables. Journal of Human Sciences, 14(1), 39-48. doi:10.14687/jhs.v14i1.4211

\begin{tabular}{|c|c|c|c|c|c|c|}
\hline $\begin{array}{l}\text { As to whether } \\
\text { there is } \\
\text { migration in } \\
\text { family }\end{array}$ & Non-available & 61 & 69.44 & 4236.0 & 1620.0 & 0.07 \\
\hline \multirow{2}{*}{$\begin{array}{l}\text { Whom he/she } \\
\text { lives with }\end{array}$} & Nuclear family & 116 & 68.92 & 7994.5 & \multirow[t]{2}{*}{1111.5} & \multirow[t]{2}{*}{0.76} \\
\hline & $\begin{array}{l}\text { Extended } \\
\text { family }\end{array}$ & 20 & 66.08 & 1321.5 & & \\
\hline
\end{tabular}

When the table 3 is analyzed, it is seen that there is significant difference between students' social emotional learning points and their ages $(\mathrm{p}<0.05)$. Accordingly, it has been found that students who are ten years old and have gone on the same class have got higher social emotional learning level than students who are nine years old. In another saying, it has been found that those who have gone on the same class and are at smaller ages have got higher social emotional learning level than those who are older ones.

Similarly, it is seen that there is significant difference between the situation on how many years they live in Izmir and their social emotional learning points $(\mathrm{p}<0.05)$. Accordingly, it has been found that students who have lived in Izmir for ten years or more have got higher social emotional learning level than those who have lived in Izmir for nine years or shorter.

On analyses which have been made, it has been determined that there is not significant difference between students' social emotional learning points and variables of gender, the situation on whether mother works or not, on whether family have migrated or not and on whom they live with in family $(\mathrm{p}>0.05)$. The results related to students' psycho-social features and their social emotional learning points are shown in table 4.

Table 4: Results of Kruskal-Wallis Test Related to Students' Psycho-Social Features and Their Social Emotional Learning Points

\begin{tabular}{|c|c|c|c|c|c|c|c|}
\hline Variables & & $\mathrm{N}$ & $\begin{array}{l}\text { Mean of } \\
\text { rank }\end{array}$ & sd & $\mathrm{X}^{2}$ & $\mathrm{p}$ & $\begin{array}{l}\text { Significant } \\
\text { difference }\end{array}$ \\
\hline \multirow[t]{4}{*}{$\begin{array}{l}\text { Number of } \\
\text { siblings }\end{array}$} & Singleton & 18 & 46.94 & 3 & 15.105 & $0.002 *$ & $\begin{array}{l}\text { Two } \\
\text { siblings- } \\
\text { singleton }\end{array}$ \\
\hline & One sibling & 50 & 59.83 & & & & \\
\hline & Two siblings & 38 & 84.39 & & & & $\begin{array}{l}\text { Three and } \\
\text { over- } \\
\text { singleton }\end{array}$ \\
\hline & $\begin{array}{l}\text { Three and } \\
\text { over }\end{array}$ & 30 & 75.75 & & & & $\begin{array}{l}\text { two } \\
\text { siblings- } \\
\text { one sibling }\end{array}$ \\
\hline \multirow{3}{*}{$\begin{array}{l}\text { Which child } \\
\text { is she/he? }\end{array}$} & First child & 55 & 65.90 & 2 & 0.793 & 0.67 & \\
\hline & Second child & 57 & 68.50 & & & & \\
\hline & $\begin{array}{l}\text { Third and } \\
\text { over }\end{array}$ & 24 & 74.46 & & & & \\
\hline \multirow[t]{3}{*}{$\begin{array}{l}\text { Mother's } \\
\text { educational } \\
\text { situation }\end{array}$} & $\begin{array}{l}\text { She has not } \\
\text { gone } \\
\text { school }\end{array}$ & 19 & 69.71 & 3 & 3.567 & 0.31 & \\
\hline & $\begin{array}{l}\text { Elementary } \\
\text { school }\end{array}$ & 52 & 64.08 & & & & \\
\hline & High school & 48 & 67.14 & & & & \\
\hline
\end{tabular}


Küçükkaragöz, H., \& Erdoğan, F. (2017). The analyzing of elementary school students' social skills and their social emotional learning levels according to some variables. Journal of Human Sciences, 14(1), 39-48. doi:10.14687/ihs.v14i1.4211

\begin{tabular}{|c|c|c|c|c|c|c|}
\hline & University & 17 & 84.53 & & & \\
\hline \multirow[t]{4}{*}{$\begin{array}{l}\text { Father's } \\
\text { educational } \\
\text { situation }\end{array}$} & $\begin{array}{lr}\text { He has not } \\
\text { gone } \\
\text { school }\end{array}$ & 12 & 66.54 & 3 & 0.274 & 0.96 \\
\hline & $\begin{array}{l}\text { Elementary } \\
\text { school }\end{array}$ & 49 & 70.27 & & & \\
\hline & High school & 53 & 68.63 & & & \\
\hline & University & 22 & 65.32 & & & \\
\hline \multirow[t]{3}{*}{$\begin{array}{l}\text { Father's } \\
\text { profession }\end{array}$} & $\begin{array}{l}\text { Liberal } \\
\text { profession }\end{array}$ & 59 & 65.07 & 2 & 0.804 & 0.804 \\
\hline & Craftman & 60 & 70.91 & & & \\
\hline & Officer & 17 & 71.91 & & & \\
\hline
\end{tabular}

According to table 4 there is significant relation between number of siblings and social emotional learning points $(\mathrm{p}<0.05)$. On analyses related to the difference's significancy; it has been determined that students who have got two siblings have got higher social emotional learning level than those who are singleton, namely, who have not got any siblings. Similarly, it has been determined that students who have got three or more than tree siblings have got higher social emotional learning level than those who are singleton and students who have got two siblings have got higher social emotional learning level than students who have got one sibling.

On the other hand, it has been determined that there is not significant difference between social emotional learning points and variables qon which sibling he/she is, mother's educational situation, father's educational situation and father's profession $(\mathrm{p}>0.05)$.

On the research which is made, if variable strings which the relations between them will be examined do not correlate with normality condition, it is analyzed with the calculation of Spearman's Rank Correlation (Can, 2014). As data from the concept of research does not correlate with normal distribution conditions, Spearman's Rank Correlation analysis has been made in order to determine on the relation between students' social skills and their social emotional learning level. The findings related to the relation between students' social skills and their social emotional learning can be seen in table 5 :

Table 5: Findings Related to The Relation between Students' Social Skill Points and Their Social Emotional Learning Level

\begin{tabular}{lll}
\hline & Values & Social Skills \\
\hline \multirow{3}{*}{ Social Emotional Learning } & $\mathrm{r}$ & 0.755 \\
\cline { 2 - 3 } & $\mathrm{p}$ & 0.000 \\
\cline { 2 - 3 } & $\mathrm{N}$ & 136 \\
\hline
\end{tabular}

As seen in table 5 the progress of Spearman's Rank Correlation which is made to reveal on whether there is a relation between students' social skill points and their social emotional learning level indicates that there is positive and significant relation at high level between students' social skills and their social emotional learning level $(\mathrm{r}=0,755 ; \mathrm{p}<0.05)$. Depending on these results, it can be said that social skills get advance as social emotional learning level increases.

\section{Conclusion, Discussion and Suggestions}

The relation between students' social emotional learning level which has got a great importance both on their academic development and social live and social skill's level with this study which is developed with elementary school's $4^{\text {th }}$ grade's students have been analyzed. Moreover, it has 
Küçükkaragöz, H., \& Erdoğan, F. (2017). The analyzing of elementary school students' social skills and their social emotional learning levels according to some variables. Journal of Human Sciences, 14(1), 39-48. doi:10.14687/ihs.v14i1.4211

been searched on whether students' social emotional learning level and their social skills' level show significant difference in terms of various variables. As a result of the research, it has been determined that students' social skills' level changes in significant level by variables of age, the situation on whether there is a migration in family or not and number of sibling. Accordingly, students who have gone on the same class education and who are ten years old have got higher social skill level than those who are nine years old; students who have migrated from a place to Izmir have got higher level than those who have not migrated; students who have got two siblings have got higher level at significant rate than students who have got one sibling and who are singleton. It is thought that for children with two siblings to share more within the family improves social skills. At the end of the study, it was determined that students with three or more siblings have lower social skill scores than students with two siblings. In this case, it can be stated that while social skills of children growing up among three siblings alongside themselves increase, those of children with four or more siblings are affected negatively. In other words, it can be thought that children cannot bring out their social abilities individually in crowded families. Uz Baş (2003) has reached the result on his research on forth and fifth grades that there isn't significant difference between class level and students' social skills (age). Ogelman and Sarrkaya (2014) determined on their researches that there is not significant difference between number of siblings and social skill level but there is significant difference between the situation on whether she/he has got a sibling and social skills. On the other hand, it is determined that there is not significant difference between social skill points and students' gender, the situation on whether mother works or not, on how many years she/he has lived in Izmir and on whom she / he lives with in family ( $p>0.05$ ). In the study conducted with university students, Dicle (2006) found out that the mean scores of social skills inventory of female students are significantly higher than those of male students. It is thought that the reason why there was not a significant difference between social skill scores at primary school level in respect to gender is that students mostly live together with their families during primary school period and that both female and male students may have similar social skills.

On the other hand, when results of the study are analyzed on the base of social emotional learning, students who have gone on the same class education and who are ten years old have got higher social emotional learning points than those who are nine years old; students who have lived in Izmir for ten years or more than ten years have got higher social emotional learning points at significant rate than those who have lived in Izmir for nine years or shorter. Moreover, students who have got two siblings have got higher social emotional learning points than those who are singleton, students who have got three or more than three siblings have got higher social emotional learning points than those who are singleton and students who have got two siblings have got higher social emotional learning points than those who have got one sibling. It can be thought that both social and emotional sharing increase in children and so children who have got two siblings have got higher social skill points and also social emotional learning points, as depending on number of sibling.

Moreover, it has been determined that there is a positive and significant relation at high rate between students' social skills' points and their social emotional learning level. The results of another study conducted with university students similarly found that there was a high-level, positive, and meaningful relationship between total social skill levels and total emotional intelligence levels of students (Dicle, 2006). At the end of the research, it can be suggested that activities which would improve students' social emotional learning and their social skills on intracurricular and also extracurricular activities are increased; group studies in intracurricular activities have been involved much more when the following situation is considered that students who have got two siblings have got higher social emotional learning level and social skill level than students 
Küçükkaragöz, H., \& Erdoğan, F. (2017). The analyzing of elementary school students' social skills and their social emotional learning levels according to some variables. Journal of Human Sciences, 14(1), 39-48. doi:10.14687/jhs.v14i1.4211

who are singleton. If there are students from different age range in the same class as the result which occurs as depending on age of students at the same class, social emotional learning programs and social skill activities which are prepared by different ages can be applied. Furthermore, it can be provided that students at different ages work together at some of activities. As the efficiency of peer learning is known, it is important to create these study groups.

\section{References}

Arslan, A. \& Akın, A. (2013). Sosyal Duygusal Öğrenme Ölçeği: Geçerlik ve Güvenirlik Çalışması. The Journal of SAU Education Faculty, 25, 23- 34.

Büyüköztürk, Ş. (2013). Sosyal Bilimler İcin Veri Analiz̨i El Kitabı (Istatistik, Araștrma Deseni, SPSS Uygulamalar ve Yorum). Ankara: Pegem Akademi.

Büyüköztürk, Ş., Çakmak, K. E., Akgün, E. Ö., Karadeniz, Ş. \& Demirel, F. (2014). Bilimsel Araștrma Yöntemleri. Ankara: Pegem Akademi.

Can, A. (2014). SPSS İle Bilimsel Arastrma Sürecinde Nicel Veri Analizi. Ankara: Pegem Akademi.

Dicle, A., N., (2006). Üniversite Öğrencilerinin Sosyal Beceri Düzeylerinin Duygusal Zeka Düzeyleri ve Bazı Kişisel Özelliklerine Göre İncelenmesi. Unpublished Master's Thesis, OnDokuz Mayıs University, Graduate School of Social Sciences, Samsun.

Durualp, E. (2014). Ergenlerin Sosyal Duygusal Öğrenme Becerilerinin Cinsiyet ve Sınıfa Göre İncelenmesi. The Journal of Academic Social Science Studies, 26, 13-25.

Elias, M. J., Zins, J. E., Weissberg, R. P., Frey, K. S., Greenberg, M. T., Haynes, N. M., Kessler, R., SchwabStone, M. E., \& Shriver, T. P. (1997). Promoting Social and Emotional Learning: Guidelines for Educators. Ascd.

Elias, M. J., (1999). Violence Preventable. Education Week. Retrieved from http://www.edweek.org/ew/articles/1999/05/19/36patti.h18.html

Goleman, D. (1995). Emotional Intellenge. Broadway Books, Newyork.

Kabakçı, Ö. F. (2006). İlköğretim İkinci Kademe Öğrencilerinin Sosyal Duygusal Öğrenme Becerileri. Unpublished Master's Thesis, Hacettepe University, Institute Of Social Sciences.

Kabakçı, Ö. F. \& Korkut, F. (2008). 6-8. Sınıftaki Öğrencilerin Sosyal-Duygusal Öğrenme Becerilerinin Bazı Değişkenlere Göre İncelenmesi. Eğitim ve Bilim, 33(148), 77-86.

Kutluay Çelik, B. (2014). The Relationship Between Social-Emotional Learning Skills and Attitudes Toward Elementary School Among Middle School Students. Unpublished Master's Thesis. Yeditepe University, Institute of Social Sciences.

Mayer, J. D. \& Salovey, P. (1995). Emotional Intelligence and The Construction and Regulation of Feelings. Applied and Preventive Psychology, 4(3), 197-208.

Ogelman, H. G. \& Sarıkaya, H., E. (2014). 5-6 Yaş Çocukların Sosyal Beceri, Akran İlişkileri ve Okula Uyum Düzeyleri ile Kardeş Değişkenleri Arasındaki İlişkiler. Akademik Bakış.14.

Özabacı, N. (2004). Öğretmen Adaylarının Duygusal Zeka ve Sosyal Beceri Düzeyleri Arasındaki İlişkinin İncelenmesi. XIII. Ulusal Eğitim Bilimleri Kurultayl, 6-9.

Özsarı, M. P. (2015). İlköğretim 4. ve 5. Sınıf Öğrencilerinin Okula Yabancılaşma ve Sosyal Beceri Düzeylerinin İncelenmesi. Mehmet Akif Ersoy University, Institute of Educational Sciences.

Payton, J., Weissberg, R. P., Durlak, J. A., Dymnicki, A. B., Taylor, R. D., Schellinger, K. B., \& Pachan, M. (2008). The Positive Impact of Social and Emotional Learning for Kindergarten to Eighth-Grade Students: Findings from Three Scientific Reviews. Technical Report. Collaborative for Academic, Social, and Emotional Learning (NJ1).

Şahin, C. (2001). Sosyal Beceri ve Sosyal Yeterlilik. Gazi University Journal of Kırşehir Education Faculty, 2(1). 11-19.

Uz Baş, A. (2003). İlköğretim 4. ve 5. Sınıflarda Okuyan Öğrencilerin Sosyal Becerileri ve Okul Uyumu ile Depresyon Düzeyleri Arasındaki İlişkinin İncelenmesi. Unpublished PhD Dissertation, Dokuz Eylül University, Institute of Educational Sciences, İzmir.

Yurdakavuştu, Y. \& Küçükkaragöz, H. (2001). Sosyal Beceri Ölçeğinin İlköğretim 5. Sınıf Öğrencileri İçin Geçerlik ve Güvenirliği. $\quad$ Retrieved from http://www.pegem.net/Akademi/sempozyumbildiri detay.aspx?id=135219

Zins, J. E. (Ed.). (2004). Building Academic Success on Social and Emotional Learning: What does the research say? Teachers College Press. 